\title{
Relationship Of Stress Levels And Diet With Blood Sugar Levels In Patients Of Type 2 Diabetes Mellitus
}

\author{
Ninik Ambar Sari*, Ceria Nurhayati, Sri Anik Rustini \\ Institute of Health Science Hang Tuah Surabaya, Indonesia \\ niniksht@gmail.com
}

\begin{abstract}
Diabetes mellitus (DM) type 2 is a condition in which the body tissue doesn't respond to the action of insulin. Type 2 DM can cause complications if it doesn't managed properly, good DM management behavior for patients needs to be done by maintaining a healthy diet and stress will increase blood sugar levels. The purpose of this study was to determine the relationship of stress levels and dietary patterns with blood sugar levels in patients with diabetes mellitus at the Klampis Ngasem Health Center in Surabaya. This study uses analytic design with cross sectional design. The sampling technique in this study was purposive sampling of 60 respondents. Data collection was carried out using a questionnaire. Data processing using the SPSS program with the Spearman Rho test with a significance value $<0.05$. Statistical test results for the stress level obtained a significant number or $\rho=0.000$ then Ho is rejected, $\mathrm{H} 1$ is accepted. This shows that there is a correlation between stress level and fasting blood glucose level of type 2 diabetes mellitus patients in Klampis Ngasem Public Health Center in Surabaya with a correlation value of 0.544 , which is located between 0.4 $<0.6$, is in the medium category. While the statistical test for dietobtained a significant number or $\rho=0.002$ then Ho is rejected, $\mathrm{H} 1$ is accepted. This shows that there is a relationship between diet and blood sugar levels of diabetes mellitus type 2 patients in Klampis Ngasem Public Health Center in Surabaya with a correlation value of 0.395 , which is located between the numbers $0.2-<0.4$ is the weak category. Discussion: The importance of the role of nurses to continue to provide information to patients with type 2 diabetes mellitus to manage diet properly and to manage stress levels to prevent increased blood sugar levels.
\end{abstract}

Key Words: Stress, Diet, Blood Sugar Level, Diabetes mellitus

Received December, 25, 2019; Revised January 24, 2020; Accepted February 15, 2020 


\section{STRADA Jurnal Ilmiah Kesehatan}

DOI: $10.30994 /$ sjik.v9i1.253

ISSN: 2252-3847 (print); 2614-350X (online)

Vol.9 No.1. May 2020. Page.241-247

\section{INTRODUCTION}

Diabetes mellitus (DM) is a collection of symptoms that arise in someone who has increased blood glucose levels due to a deficiency of the insulin hormone in absolute or relative terms (Isselbacher, 2012). Based on type DM is divided into 2, namely type 1 (insulin dependent), and type 2 (non insulin dependent). Type 2 DM is a chronic metabolic disorder characterized by an increase in blood sugar levels due to decreased insulin secretion by pancreatic beta cells and / or insulin function (insulin resistance). DM type I occurs in about 90-95\% of sufferers, usually occurs in diabetics over the age of 30 years and obese (Smeltzer \& Bare, 2013).

The number of world population affected by diabetes mellitus is increasingly worrying. According to the World Health Organitation (WHO), the number of people affected by diabetes mellitus in 2015 reached 415 million more people and by 2040 it is estimated that the number of diabetics in the world will increase to reach 642 million people or an increase of $70 \%$ in the period 25 years. Indonesia ranks fifth largest in the number of people with diabetes mellitus with a prevalence of $6.67 \%$ of the total population of 258 million (IDF, 2015).

The number of people with Type $2 \mathrm{DM}$ is increasing in Indonesia caused many factors, including heredity/genetic factors, obesity, lifestyle changes, stress, wrong diet, drugs that affect blood glucose levels, lack of physical activity, aging, pregnancy, and smokers (Damayanti, 2015). At this time there are still many people in Indonesia who don't provide fiber foods, foods rich in cholesterol, fat, sodium (in flavoring salts) appear as daily menu trends which are also exacerbated by the increasing consumption of foods and drinks that are rich in sugar. Many people see that diagnosis of Type 2 DM is a statement of bad luck, a statement of punishment and often someone who has diabetes will experience fear if he cannot control his life. If this situation is not resolved, it can cause stress which can later affect blood sugar in a few minutes later. The body will increase blood sugar and there is an energy reserve for activity when under stress. The body is indeed designed in such a way as to have a good purpose. However, prolonged stress without a solution, is tantamount to slow suicide (Fauzi, 2014).

Diabetes mellitus that isn't handled properly and properly can cause various kinds of complications in body organs such as eyes, heart, kidneys, blood vessels and nerves that will endanger the lives of diabetics. Complications obtained in a person due to the length of DM suffered causes both acute and chronic. Acute complications arise when there is a sudden decrease or increase in blood glucose levels while chronic complications arise with the effect of an increase in blood glucose levels for a long time. These complications can cause a person's short life span, self-limitation and increased economic burden for clients and their families, so it greatly affects the decline in the quality of life of patients if they do not get proper treatment (Smeltzer \& Bare, 2013).

Stress isn't immediately addressed or managed properly, it will be able to have further impacts such as easily occurring disorders or more severe disease. In order for diabetic patients to control their blood glucose levels they need to pursue a healthy lifestyle and manage their stress levels. Preventing and dealing with stress so that it does not get to the most severe stages of stress management (Buckman \& Mclaughlin, 2010). People with DM must maintain their diet by implementing and applying the 3 right principle, which is a fixed meal schedule, choosing the right type of food for diabetes, and the amount of food containing energy sources such as carbohydrates, proteins and fats that meet the body's adequacy, in addition it checks 
STRADA Jurnal IImiah Kesehatan

DOI: $10.30994 /$ sjik.v9i1.253

ISSN: 2252-3847 (print); 2614-350X (online)

Vol.9 No.1. May 2020. Page.241-247

glucose levels more often when you are sick or under stress and drink lots of fluids to avoid dehydration (Moore, 2012).

\section{OBJECTIVE}

This study aimed to determine the result of the relationship of stress levels and diet to blood sugar levels in patients with Diabetes Mellitus.

\section{METHODS}

This study uses a quantitative approach with a cross-sectional research design that emphasizes the measurement time or observation of independent variable data about fasting blood sugar in type $2 \mathrm{DM}$ patients and the dependent variable about stress levels and dietin type $2 \mathrm{DM}$. The independent variables and the dependent variable are only assessed one time at a time. The study was conducted in the working area of Klampis Ngasem Public Health Center in Surabaya November-December 2019. The population in this study were all Diabetes Mellitus sufferers in December 2019 who participated in Prolanis activities as many as 63 respondents, a total sample of 60 respondents. The sampling technique used in this study was purposive sampling, which is the sampling technique determined by the researcher with certain requirements (Arif, 2013).

Inclusion criteria in this study: male / female patients, patients participating in Prolanis activities at the Klampis Ngasem Health Center, laboratories (GDP levels), patients present at the time of data collection, patients who are willing to become respondents. Whereas the exclusion criteria: patients who cannot read, refuse to become respondents.

The principles in the ethics of this research are Informed Consent, Anonymity, Confidentiality. The collected data is then processed through the stages of: Editting, Coding, Data Entry, Cleaning. Data analysis in this research was carried out through two stages, namely univariate analysis and bivariate analysis.

\section{RESULTS}

This study is a correlative descriptive study aimed at analyzing the relationship between stress levels and dietary patterns with fasting blood sugar levels of diabetes mellitus patients at the Puskesmas Klampis Ngasem Surabaya. The study was conducted on 66 people with diabetes mellitus at the Klampis Ngasem Public Health Center in Surabaya. Furthermore, the results of the study are presented as follows.

\section{Characteristics of Respondents}

Based on the results of data collection and data analysis, the characteristics of the respondents are shown in the following table.

Table 1 Frequency Distribution of Respondent Characteristics $(n=60)$

\begin{tabular}{llcc}
\hline No & \multicolumn{1}{c}{ Characteristic } & Frequency & Percentage (\%) \\
\hline 1. & Gender & 19 & 32 \\
& a. Male & 41 & 68 \\
& b. Female & & \\
2. Age & 25 & 42 \\
& a. $40-55$ years & 32 & 53 \\
b. $56-75$ years & 3 & 5 \\
c. $>75$ years & & \\
\hline
\end{tabular}

Website: https://sjik.org/index.php/sjik | Email: publikasistrada@gmail.com 
3. Work
a. Housewive
b. Doesn't work
c. Entrepreneur
d. PNS

4. Pendidikan
a. SD
3
5
b. SMP
29
48
c. SMA
15
25
d. S1

5 Duration of DM Diagnosis
a. <3 years
12
20
b. $3-5$ years
26
43
c. 6-10 years
18
30
d. $>10$ years
4 7

The results of data analysis about the characteristics of the respondents showed that the majority were female as many as 41 respondents (68\%). The characteristics of the respondents' age showed that most of them were 56-75 years old as many as 32 respondents (53\%). Characteristics of most jobs, housewive many as 27 respondents (45\%), while the length of diagnosis of DM most respondents are 3-5 years suffer from DM as much as 26 respondents (43\%).

Bivariate Analysis Results

Table 2. Data on the Relationship between Stress Level and Blood Sugar Levels of Type 2 Diabetes Mellitus Patients in Klampis Ngasem Health Center Surabaya

\begin{tabular}{|c|c|c|c|c|c|c|c|c|}
\hline \multirow{3}{*}{ Stress } & \multicolumn{8}{|c|}{ Blood Sugar Level } \\
\hline & \multicolumn{2}{|c|}{ Good } & \multicolumn{2}{|c|}{ Medium } & \multicolumn{2}{|c|}{ Bad } & \multicolumn{2}{|c|}{ Total } \\
\hline & $\mathbf{F}$ & $\%$ & $\mathbf{F}$ & $\%$ & $\mathbf{F}$ & $\%$ & $\sum$ & $\%$ \\
\hline Normal & 0 & 0 & 5 & 100 & 0 & 0 & 5 & 100 \\
\hline Light Stress & 9 & 23.7 & 29 & 76.3 & 0 & 0 & 38 & 100 \\
\hline Moderate Stress & 0 & 0 & 7 & 41.2 & 10 & 58.8 & 17 & 100 \\
\hline Total & 9 & 15 & 41 & 68.3 & 10 & 16.7 & 60 & 100 \\
\hline $\begin{array}{l}\text { Spearman } \\
\text { From the Spearma } \\
\text { then Ho is rejected } \\
\text { and fasting blood } \\
\text { Health Center in } \\
<0.6 \text {, is in the med }\end{array}$ & tati & $\begin{array}{l}\text { Test R } \\
\text { al test } \\
\text { This } \\
\text { ype } 2 \text { c } \\
\text { correla }\end{array}$ & $\frac{\text { with }}{\text { ts ol }}$ & $\begin{array}{l}\text { lue } \mathrm{p} \\
\text { ed a si } \\
\text { e is a } \\
\text { is pati } \\
.544\end{array}$ & ican & $\begin{array}{l}\text { ue } \mathrm{r}= \\
\text { umber } \\
\text { betwe } \\
\text { npis N } \\
\text { cated }\end{array}$ & $\begin{array}{l}\frac{544}{\mathrm{r} \rho} \rho \\
\text { stre } \\
\text { asem } \\
\text { twee }\end{array}$ & $\begin{array}{l}0.000 \\
\text { level } \\
\text { Public } \\
0.4 \text { - }\end{array}$ \\
\hline
\end{tabular}


STRADA Jurnal Ilmiah Kesehatan

DOI: $10.30994 /$ sjik.v9i1.253

ISSN: 2252-3847 (print); 2614-350X (online)

Vol.9 No.1. May 2020. Page.241-247

Table 3. Data on the Relationship between Diet and Blood Sugar Levels of Type 2 Diabetes Mellitus Patients in Klampis Ngasem Health Center Surabaya

\begin{tabular}{|c|c|c|c|c|c|c|c|c|}
\hline \multirow{3}{*}{ Diet } & \multicolumn{8}{|c|}{ Fasting Blood Sugar Levels } \\
\hline & \multicolumn{2}{|c|}{ Good } & \multicolumn{2}{|c|}{ Medium } & \multicolumn{2}{|c|}{ Bad } & \multicolumn{2}{|c|}{ Total } \\
\hline & $\mathbf{F}$ & $\%$ & $\mathbf{F}$ & $\%$ & $\mathbf{F}$ & $\%$ & $\sum$ & $\%$ \\
\hline Good & 6 & 17.6 & 28 & 82.4 & 0 & 0 & 5 & 100 \\
\hline $\mathrm{Bad}$ & 3 & 11.5 & 13 & 50 & 10 & 38.5 & 26 & 100 \\
\hline Total & 9 & 15 & 41 & 68.3 & 10 & 16.7 & 60 & 100 \\
\hline
\end{tabular}

From the Spearman's Rho statistical test results obtained a significant number or $\rho=0.002$ then Ho is rejected, H1 is accepted. This shows that there is a relationship between diet and fasting blood sugar levels of type 2 diabetes mellitus patients in Klampis Ngasem Public Health Center in Surabaya with a correlation value of 0.395 , which is located between the numbers $0.2-<0.4$ is the weak category.

\section{DISCUSSION}

The characteristics of responsive work are mostly housewives with 27 respondents $(45 \%)$. As a housewife, the respondent will do housewife activities that can unconsciously help control the respondent's blood sugar levels. According to Tandra (2009), physical activity carried out by housewives such as sweeping, going up and down stairs, ironing, gardening and exercising causes depression and anxiety and stress, especially in those who experience menopause and old age. Stress trigger factors based on the stage of development of the elderly include old age (aging process), changes in residence, adjustment in retirement and the process of death. Characteristics of responsive sex are mostly female as many as 41 respondents $(68 \%)$.

A 2011 study by the American Psychological Association Report found that women tend to be more affected by stress. This makes them feel more anxious, and more often experience stress than men (Beck, 2011). People's response to stress depends on learning experiences, gender, medical conditions and genetic tendencies to experience high blood pressure, heart disease, obesity, diabetes or other health problems (Wade \& Carol, 2007).

Table 2 Spearman's Rho statistical test results obtained a significant number or $\rho=0.000$ then Ho is rejected, H1 is accepted. This shows that there is a correlation between stress level and fasting blood sugar level of type 2 diabetes mellitus patients in Klampis Ngasem Health Center Surabaya. The hypothesized relationship is a physiological reaction to stress that can affect the hypothalamic axis which further controls the two neuroendocrine systems, namely the sympathetic system and the adrenal cortex system. Activating various organs, the sympathetic nervous system responds to nerve impulses from the hypothalamus. The sympathetic nervous system also signals the adrenal medulla to release epinephrine and norepinephrine into the bloodstream. The adrenal cortex system is activated if the hypothalamus secretes corticotropin releasing factor (CRF), a chemical acting on the pituitary gland located just below the hypothalamus. The pituitary gland then secretes the hormone adrenocorticotropic hormone (ACTH), which is carried through the bloodstream to the adrenal cortex and will stimulate the release of hormones including glucagon which stimulates the liver, muscles, fat tissue to release energy stored there (Dalami, 2010). In addition it stimulates the secretion of glucagon, epinephrine apparently has an antagonistic effect on 


\section{STRADA Jurnal Ilmiah Kesehatan}

DOI: $10.30994 /$ sjik.v9i1.253

ISSN: 2252-3847 (print); 2614-350X (online)

Vol.9 No.1. May 2020. Page.241-247

insulin function and inhibits insulin-induced glucose transport in peripheral tissues. These hormonal changes trigger maximal gluconeogenesis and interfere with peripheral glucose, causing severe hyperglycemia. At the time of stress the body will increase energy reserves and blood sugar while on the move. So that stress is prolonged without a way out, is tantamount to slow suicide (Fauzi, 2014). In times of psychological stress, diabetics can change their diet, exercise and use of drugs that are usually obeyed to be ignored by sufferers.

According to education researchers influence a person to choose and determine the food to be consumed, the higher a person's education the higher the choice of foods that have more nutrition, this can affect one's health, especially diabetic patients. However, the results of the study mentioned a high diet in diabetic patients at the Klampis Ngasem Public Health Center in Surabaya with the most education being 29 respondents (48\%), because patients chose foods containing less fat and high protein, as well as excessive carbohydrate consumption, if this activity allowed to interfere with insulin so that blood glucose levels can increase. In accordance with Sherwood's theory (2014) which states that if the body lacks carbohydrates, there will be a consumptive increase between fat and protein to be converted into energy for the body's metabolism. Poor diet occur as a result of a lack of patient information and the lack of getting information about a healthy and balanced diet so that the fulfillment of energy a day becomes deficient and even excessive. Economic factors that are quite dominant in influencing food consumption are family income and prices. An increase in income will increase opportunities to buy food with better quantity and quality, on the contrary a decrease in income will cause a decrease in the purchasing power of food both in quality and quantity (Handayani, 2012).

Table 3 Spearman's Rho statistical test results obtained a significant number or $\rho=0.002$ then Ho is rejected, H1 accepted. This shows there is a relationship between diet and fasting blood sugar levels of type 2 diabetes mellitus patients at Klampis Ngasem Health Center. Diet play an important role for someone with DM who can not manage the diet with $3 \mathrm{~J}$ settings (schedule, type and amount) then this will cause patients to experience increased blood sugar levels (Suiraoka, 2012). The diet of DM sufferers must really be considered.

\section{CONCLUSION}

This study shows a relationship between stress levels and dietary patterns with fasting blood sugar levels in patients with type 2 Diabetes Mellitus at the Klampis Ngasem Health Center in Surabaya. Respondents are recommended that controlling their blood glucose levels need to strive for a healthy lifestyle and manage their stress levels while maintaining the stability of their blood sugar levels by adjusting appropriate dietary patterns in accordance with the $3 \mathrm{~J}$ recommendations (Schedule, Amount and Type).

\section{REFERENCES}

Arif, S. (2013). Statistika Penelitian. Jakarta : Rineka Cipta

Beck, Mary E. (2011). Ilmu Gizi dan Diet: Hubungannya dengan Penyakit-penyakit untuk Perawat \& Dokter. Yogyakarta: Yayasan Essentia Medica (YEM).

Buckman, Robert dan Mclaughlin, Chris. (2010). Apa Yang Seharusnya Anda Ketahui Tantang: Hidup Dengan Diabetes, Edisi Revisi. Yogyakarta: Citra Aji Parama.

Dalami, Ermawati. 2010. Konsep Dasar Keperawatan Kesehatan Jiwa.Jakarta: Trans Info Media. 


\section{STRADA Jurnal Ilmiah Kesehatan}

DOI: $10.30994 /$ sjik.v9i1.253

ISSN: 2252-3847 (print); 2614-350X (online)

Vol.9 No.1. May 2020. Page.241-247

Damayanti, S. (2015). Diabetes Mellitus \& Penatalaksanaan Keperawatan. Yogyakarta : Nuha Medika

Fauzi, Isma. (2014). Buku Pintar Deteksi Dini Gejala \& Pengobatan Asam Urat, Diabetes, Hipertensi. Yogyakarta: Araska.

Handayani, Irma. (2012). Gambaran Pola Makan Suku Melayu dan Suku Jawa di Desa Selemak Kecamatan Hamparan Perak Kabupaten Deli Serdang, Fakultas Kesehatan Masyarakat Universitas Sumatera Utara, diakses tanggal 5 Januari 2020, $<$ http://repository.usu.ac.id $>$.

Isselbacher. (2012). Prinsip-Prinsip Ilmu Penyakit Dalam Volume 5 Edisi 13. (Terjemahan). Jakarta: EGC

IDF. (2015). IDF Diabetes Atlas Sixth Edition Update, International Diabetes federation 2014.

Moore, Mary Courtney. (2012). Buku Pedoman: Terapi Diet dan Nutrisi, Edisi 2. Jakarta: Hipokrates

Tandra. (2009). Segala Sesuatu Yang Harus Anda Ketahui Tentang Diabetes. Jakarta: Kompas Gramedia.

Sherwood, Lauralee. (2014). Fisiologi Manusia Dari Sel Ke Sistem, Edisi 6. Jakarta: EGC.

Smeltzer, S.C \& Bare, B.G (2013). Buku Ajar Keperawatan Medikal Bedah Brunner\& Suddarth, edisi 8. Jakarta: EGC.

Suiraoka. (2012). Penyakit Degeneratif . Yogyakarta: Nuhamedika.

Wade, Carole dan Carol Tavris. (2007). Psikologi, Edisi Sembilan Jilid 2. Jakarta: Penerbit Erlangga. 